\title{
Evaluation of Gamma Irradiation Effect on the Oxidative Stress Factors in Septic Rats Treated With Iranian Plant Essential Oils
}

\author{
Faezeh Fatemi ${ }^{1 *}$, Atefeh Jalali Yazdi ${ }^{2}$, Shirin Ghanooni ${ }^{2}$, Mohammad Reza Zolfaghari ${ }^{\mathbf{2}}$. \\ ${ }^{1}$ Materials and Nuclear Fuel Research School, Nuclear Science and Technology Research Institute, Tehran, Iran; ${ }^{2}$ \\ Department of Microbiology, Qom Branch, Islamic Azad University, Qom, Iran.
}

\begin{abstract}
Cuminum cyminum L. (CM), Zataria multiflora Boiss. (ZM) and Mentha piperita L. (MP) are traditional medicinal plants with various pharmacological properties. This study was designed to assess the role of gamma irradiation -a modern decontamination method-in hepatoprotective effects of their essential oil $\left(E . O_{s}\right)$ in septic rats induced by experimental cecal ligation and puncture (CLP) model. The rats were divided into 20 groups; sham-operated (SOP); CLP; CLP + CM, ZM and MP (E.Os) $(100 \& 200 \mathrm{mg} / \mathrm{kg} \mathrm{b.w})$ and CLP + gamma irradiated (10 and $25 \mathrm{kGy})$ E. $O_{s}(100 \& 200 \mathrm{mg} / \mathrm{kg}$ b.w $)$ as treatment groups. All E. $O_{s}$ were injected i.p immediately after sepsis induction. 24 hour after $C L P$, the rats were sacrificed and the liver tissue was examined considering lipid peroxiation $(L P)$, glutathione (GSH) and myeloperoxidase (MPO) activity. The results indicated that CLP operation caused significant $(P<0.05)$ increase in the LP and MPO levels concomitant with decreased GSH level. Administration of the E. $O_{s}(100$ and $200 \mathrm{mg} / \mathrm{kg}$ b.w) extracted from non irradiated plants as well as the irradiated (10 and $25 \mathrm{kGy}$ ) plant E. $O_{s}$ could significantly $(P<0.05)$ modulate the levels of $L P, M P O$ and GSH. It can be concluded that all E. $O_{s}$ even after irradiation exposure could modulate the oxidative injury parameters related to liver damages in CLP rat model. In conclusion, the plant irradiation didn't have any adverse effects on the hepatoprotective activities of the extracted oils.
\end{abstract}

Key words: Essential oils, Oxidative stress, Antioxidant, CLP, Gamma irradiation

\footnotetext{
*Author for correspondence: ffatemi@aeoi.org.ir
} 


\section{INTRODUCTION}

Sepsis is a potentially life-threatening complication of a systemic infection due to the microorganism or its toxin on the blood. Sepsis is one of the most important public health concerns and is the leading cause of morbidity and mortality in intensive care unit (ICU) ${ }^{1}$. The oxygen-free radicals produced during sepsis can cause oxidative stress leading to multi-organ failure via several mechanisms including the peroxidation of membrane lipids, increasing the myleoperoxidase (MPO) activity and decreasing the glutathione (GSH) levels ${ }^{2-6}$.

In regards to the increasing occurrence of resistance and side effects of antibiotics and other synthetic drugs in sepsis treatment, medicinal plants with determined antibacterial and antioxidant activities could be appropriate alternative treatments.

Zataria multiflora Boiss. (ZM) (Family Lamiaceae) known as Avishan-e-Shirazi geogrifically grow in Iran, Pakistan and Afghanestan ${ }^{7}$. It is used in Iranian traditional medicinal such as antiseptic, antispasmodic and anesthetic agent ${ }^{8}$. Its essential oils $\left(\right.$ E. $\left.\mathrm{O}_{\mathrm{s}}\right)$ and extracts exhibited the antibacterial activity against the different positive and negative gram bacteria as well as strong antioxidant and protective activities ${ }^{9-12}$. Cuminum cyminum L. (CM) as an aromatic plant in Apiaceae family cultivated in Asia, Africa and Europe ${ }^{13}$. In folk medicine, it is widely used as carminative, antispasmodic and appetite stimulant agents ${ }^{14}$. The antioxidants, chemopreventive and antibacterial activities of MP oils have been previously confirmed ${ }^{15-19}$. Mentha piperita L. (MP) with common name peppermimnt belonging to Lamiaceae family originated from Mediterranean region and also cultivate all over the world. The plant are commonly used in folk medicine for carminative, antispasmodic, antiemetic, diaphoretic, analgesic, anti-inflammatory, stimulant, emmenagogue and anticatharrhal applications. Its essential oils are generally used externally for antipruritic, astringent, rubefacient, antiseptic and antimicrobial purposes, and for treating neuralgia, myalgia, headaches and migraines ${ }^{19-28}$

In addition, gamma-irradiation is the process of exposing products to radiation to delay ripening, inhibit sprouting and extend shelf-life by reducing spoilage organisms, helping to meet quarantine standards for export to foreign markets ${ }^{29}$. The gamma irradiation method is allowed for the decontamination of dried herbs, spices and vegetable seasonings with a maximum overall average absorbed dose of $10 \mathrm{kGy}$ but this limitation has been raised by the Food and Drug Administration (FDA) to doses of $30 \mathrm{kGy}$ for these products ${ }^{25,26}$.

One of the most problems using gamma irradiation is the adverse effects on the biological activities of the medicinal plants ${ }^{30-31}$. So, the investigation of the irradiation effects on the biological and therapeutical properties of the medicinal plants cannot be ignored. Most recent studies were focused on the possible changes in the biochemical properties of medicinal plant during irradiation. Our recent studies also confirmed that the antioxidant, antibacterial and antiseptic activities of the essential oils and extracts obtained from the different medicinal plants such as Carum carvi, ZM, MP and CM didn't change due to gamma irradiation up to $25 \mathrm{kGy}^{32-38}$. In followings, the present study aimed to evaluate the effect of gamma irradiation at two doses (10 and $25 \mathrm{kGy})$ on the hepatoprotective abilities of E. $\mathrm{O}_{\mathrm{s}}$ derived from three Iranian endemic medicinal plants e.g. ZM aerial parts, MP leaves and CM seeds in cecal ligation and puncture CLP rat model. 
Anti-septic activity of irradiated plant oils

\section{MATERIALS AND METHODS}

\section{Plant irradiation and oil extraction}

Zataria multiflora Boiss. aerial parts, Mentha piperita L. leaves and Cuminum cyminum L. seeds collected from Shiraz, Isfahan and Kerman cities of Iran, respectively. They were characterized by an expert botanist Mr. Bagherzadeh (Research in Forests and Rangelands institute, Isfahan, Iran).

The plants were packed in 3 batches $(50 \mathrm{~g})$ in heat-sealed polyethylene pouches and passed by a $\mathrm{Co}^{60}$ source for irradiation at two doses (10-maximum approved dose for decontamination of food supply- and $25 \mathrm{kGy}$ - sterile dose-) using a high dose rate research irradiator $\left(\mathrm{Co}^{60}\right.$ - Gamma cell 220 (A.E.C.L $\left.{ }^{1}\right)$; Canada) calibrated with Frick standard dosimeter which is installed in Radiation Application Research School of Atomic Energy Organization of Iran. The dose was controlled by the exposure time of each container to the source. The temperature and dose rate for all the samples were $22-23{ }^{\circ} \mathrm{C}$ and $0.37 \mathrm{~Gy} / \mathrm{s}$, respectively. The dose range within the samples was $\pm 20 \%$ of the actual dose. The control and irradiated samples were stored in plastic containers at room temperature $\left(28-30^{\circ} \mathrm{C}\right)$ under the same conditions ${ }^{32-35}$.

In following, the CM, ZM and MP samples before and after gamma irradiation were subjected to oil extraction using a Clevenger-type apparatus. The extraction was carried out for $2 \mathrm{~h}$ and the oils were stored in dark glass bottles in a freezer until further use $^{32-35}$

\section{Animal treatments and experimental design}

A total of 100 male Wistar rats (260-280 g) were used in this study. All rats were obtained from Qom Azad University's experimental and research animal laboratory. Rats were maintained at $23^{\circ} \mathrm{C}$ with access to standards rat food and tap water $a d$ libitum.

The animal studies had been approved by the Medical Ethics Committee of Tarbiat Modares University based on the World Medical Association Declaration of Helsinki. The animals were acclimated to the laboratory environment for at least 1 week prior to surgical manipulation. The rats were randomly divided in 20 groups ( $=5)$; In Shamoperated group (Group 1) (SOP), rats undergone laparotomy and received DMSO as vehicle. In CLP group (Group 2), animals received vehicle alone after CLP operation. In CLP treated groups (Groups 3-8), E.O of all three non irradiated plants (100 and $200 \mathrm{mg} / \mathrm{kg}$ b.w) diluted in DMSO, were injected intraperitoneally (i.p) immediately after CLP operation. In CLP treated groups (Groups, 9-20), irradiated (10 and $25 \mathrm{kGy}$ ) E. $\mathrm{O}_{\mathrm{s}}$ of all three plants $(100$ and $200 \mathrm{mg} / \mathrm{kg} \mathrm{b.w})$. Then, $24 \mathrm{~h}$ after CLP surgery, the liver tissues were removed, washed and processed for biochemical analysis. In addition, blood samples were collected for CFU count ${ }^{10}$.

\section{CLP model}

Polymicrobial sepsis in rats was induced by CLP according to the method of Hubbard ${ }^{3}$. Briefly, the rats were anesthetized by injection (i.p) of ketamine $(90 \mathrm{mg} / \mathrm{kg} \mathrm{b} . \mathrm{w})$ and xylazine $(10 \mathrm{mg} / \mathrm{kg} \mathrm{b.w})$ mixture. A small mid abdominal incision $(2-3 \mathrm{~cm})$ was made and the cecum was exposed. A distended portion of the cecum just distal to the ileocecal valve was isolated, filled with fecal content, and tied with a 3-O silk suture in a manner not to disrupt bowel continuity. The ligated portion of the cecum was punctured twice with a 20 -gauge needle. The cecum was then replaced in its original position within the abdomen and the abdomen was then closed with a 3-O suture in two layers. Then, the animals were allowed to recover. In the sham-operated rat, the cecum was exposed, manipulated and returned to the peritoneal cavity without being 
punctured. After surgery, normal saline ( $3 \mathrm{ml} / 100 \mathrm{~g} \mathrm{b.w}$ ) was given subcutaneously to all rats to prevent dehydration ${ }^{38}$.

\section{Colony forming units (CFUs) determination}

Blood was obtained under ether anesthesia from the heart puncture and immediately serially diluted 10 -fold in sterilized salt solution. The diluted blood was transferred rapidly to BHI plates and placed into incubator for $48 \mathrm{~h}$ at $37^{\circ} \mathrm{C}{ }^{30}$. The number of colonies was counted using a colony counter (Sana, Iran) ${ }^{38}$.

\section{Biochemical analysis}

Measurement of myeloperoxidase (MPO) activity in liver

Tissue MPO activity was measured, with minor modification, by according to the procedure of Hillegas ${ }^{39}$. Weighed tissue samples were homogenized in $50 \mathrm{mM}$ potassium phosphate buffer ( $\mathrm{pH}$ 6.0) and centrifuged at $41400 \mathrm{~g}$ for $10 \mathrm{~min}$. After discarding the supernatant, the pellets were suspended in a solution containing $0.5 \%$ hexadecyl-trimethyl-ammonium bromide dissolved in $1 \mathrm{ml}$ potassium phosphate buffer ( $\mathrm{pH}$ 6.0). In following to three freeze-thaw cycles, the samples were centrifuges at $41400 \mathrm{~g}$ for $10 \mathrm{~min}$. MPO activity was determined by adding $150 \mu \mathrm{L}$ of the supernatant to $1150 \mathrm{~mL}$ of $10 \mathrm{mmol} / \mathrm{L}$ phosphate buffer $(\mathrm{pH} 6.0)$ and $1 \mathrm{~mL}$ of 1.5 $\mathrm{mmol} / \mathrm{L}$ o-dianisidine hydrochloride containing hydrogen peroxide. The absorbance at $460 \mathrm{~nm}$ was measured for $1 \mathrm{~min}$ and the rate of change in the absorbance was used to calculate the activities of MPO. MPO activity was expressed as the amount of enzyme that reduces $1 \mu \mathrm{mol}$ peroxide/min.

Measurement of TBARSs as lipid peroxidation products in liver

The concentration of TBARS was measured spectrophotometrically using TBA reagent based on the procedure described by Buege and Aust ${ }^{40}$. Briefly, a weighed portion of the liver was homogenized in phosphate buffer (100 mM, pH 7.0) and used to measure the level of thiobarbituricacid reactive substances (TBARS) as indices for lipid peroxidation. The homogenate $(1 \mathrm{~mL})$ was added to $2 \mathrm{ml} \mathrm{TBA}$ reagent and was shaken for $15 \mathrm{~min}$. The mixture was incubated for $15 \mathrm{~min}$. After cooling, the mixture was centrifuged at $3000 \mathrm{~g}$. The absorbance at $535 \mathrm{~nm}$ was measured. The results were expressed as nanomole of TBARS per gram of tissue (nmol TBARS/g liver).

\section{Measurement of GSH}

GSH level was estimated in liver homogenate according to the procedure of Sedlak and Lindsay ${ }^{41}$. A weighed portion of the liver was homogenized in EDTA $0.02 \mathrm{M}$. The $5 \mathrm{ml}$ of homogenate was immediately precipitated with $1 \mathrm{ml}$ of $50 \%$ trichloroacetic acid and $4 \mathrm{ml}$ distilled water; the precipitate was removed after centrifugation at 3000 $\mathrm{g}$ for $15 \mathrm{~min}$. To determine the GSH level, the $2 \mathrm{ml}$ of supernatantwas mixed with $4 \mathrm{ml}$ Tris-buffer $(0.4 \mathrm{M})$, containing EDTA $(0.2 \mathrm{M})$ and $0.1 \mathrm{ml}$ 5,5-dithiobis (2-nitrobenzoic acid) $(0.01 \mathrm{M})$. Absorbance was measured at $412 \mathrm{~nm}$ using a spectrophotometer. The results of the GSH levels in the liver were expressed as micromoles per milligram of tissue $(\mu \mathrm{mol} / \mathrm{g}$ liver).

\section{Statistical analysis}

Data are presented as means \pm Standard Error (SE). The results were subjected to oneway ANOVA followed by Tukey's HSD (Honestly Significant Differences) using SPSS 22.0 software. The significance was considered as $P<0.05$. 
Anti-septic activity of irradiated plant oils

\section{RESULTS}

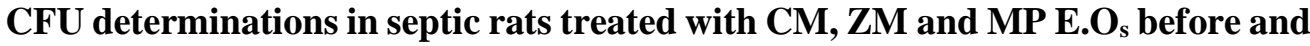 after gamma irradiation:}

The blood bacterial load was determined by CFU count at $24 \mathrm{~h}$ after CLP, were shown in Table 1. CFU was significantly higher (in the blood of the CLP group in comparison to laparatomy group $(P<0.05)$. Treatments of rats with non irradiated CM E. $\mathrm{O}_{\mathrm{s}}$ could significantly $(P<0.05)$ decrease the bacterial load at $100 \mathrm{mg} / \mathrm{kg} \mathrm{b.w}$ and $200 \mathrm{mg} / \mathrm{kg}$ b.w. Also, the administration of non -irradiated ZM E. $\mathrm{O}_{\mathrm{s}}$ could surprisingly diminish the CFU at $100 \mathrm{mg} / \mathrm{kg}$ b.w and $200 \mathrm{mg} / \mathrm{kg} \mathrm{b.w} \mathrm{compared} \mathrm{to} \mathrm{the} \mathrm{CLP} \mathrm{group}(P<0.05)$. Indeed, the bacterial load considerably $(P<0.05)$ declined in the groups treated with 100 and $200 \mathrm{mg} / \mathrm{kg}$ b.w of MP E.O s $_{\text {s }}$ in compared to the CLP groups. Based on our statistical analysis, there is no significant difference between 100 and $200 \mathrm{mg} / \mathrm{kg} \mathrm{b.w}$ doses on the reduction of $\mathrm{CFU}(P>0.05)$.

Table No.1: Blood bacterial number $(\mathrm{CFU} / \mathrm{ml})$ in sepsis rats treated with Z. multiflora Boiss. (ZM), Cuminum cyminum L. (CM) and Mentha piperita L. (MP) E. $\mathrm{O}_{\mathrm{s}}$ before and after gamma irradiation

\begin{tabular}{|c|c|c|c|}
\hline Groups & Bacterial counts & & \\
\hline & $\begin{array}{l}\text { Cuminum cyminum } \\
\text { (CM) }\end{array}$ & $\begin{array}{l}\text { Zataria multiflora } \\
(\mathrm{ZM})\end{array}$ & $\begin{array}{l}\text { Mentha piperita L. } \\
\text { (MP) }\end{array}$ \\
\hline Laparotomy (DMSO) & 0 & 0 & 0 \\
\hline CLP (DMSO) & $22172 \pm 850^{*}$ & $22170 \pm 850^{*}$ & $22172 \pm 850^{*}$ \\
\hline $\begin{array}{l}\text { CLP + non-irradiated E.Os } \\
(100 \mathrm{mg} / \mathrm{kg} \mathrm{b.w})\end{array}$ & $4820 \pm 37^{* *}$ & $5000 \pm 1100^{* *}$ & $680 \pm 492^{* *}$ \\
\hline $\begin{array}{l}\text { CLP + Irradiated E.Os (10 kGy) } \\
(100 \mathrm{mg} / \mathrm{kg} \text { b.w) }\end{array}$ & $6240 \pm 30^{* *}$ & $5040 \pm 1115^{* *}$ & $7788 \pm 4804^{* * *}$ \\
\hline $\begin{array}{l}\text { CLP + Irradiated E.Os (25 kGy) } \\
(100 \mathrm{mg} / \mathrm{kg} \text { b.w) }\end{array}$ & $4985 \pm 20^{* *}$ & $1800 \pm 40^{* *}$ & $2580 \pm 1622^{* *}$ \\
\hline $\begin{array}{l}\text { CLP + non-irradiated E.Os } \\
(200 \mathrm{mg} / \mathrm{kg} \text { b.w })\end{array}$ & $20 \pm 2^{* *}$ & $6380 \pm 1060^{* *}$ & $8220 \pm 4836^{* *}$ \\
\hline $\begin{array}{l}\text { CLP + Irradiated E.Os (10 kGy) } \\
(200 \mathrm{mg} / \mathrm{kg} \text { b.w })\end{array}$ & $28 \pm 2.2^{* *}$ & $5300 \pm 896^{* *}$ & $63 \pm 0.3^{* * *}$ \\
\hline $\begin{array}{l}\text { CLP + Irradiated E.Os (25 kGy) } \\
(200 \mathrm{mg} / \mathrm{kg} \text { b.w) }\end{array}$ & $40 \pm 3^{* *}$ & $3220 \pm 720^{* * *}$ & $40 \pm 4^{* *}$ \\
\hline
\end{tabular}

In Sham- operated group (SOP), rats were undergone laparotomy and received DMSO as vehicle; In CLP group, the CLP operation was done and animals received vehicle alone; CLP+ essential oils (E.Os) groups, E.Os (100 \& $200 \mathrm{mg} / \mathrm{kg}$ b.w) were injected (i.p) immediately after CLP operation. Values of mean \pm SEM obtained from five rats. $* \mathrm{P}<0.05$ is considered significantly different from laparatomy group. $* * \mathrm{P}<0.05$ is considered significantly different from CLP group within each group.

In addition, the essential oils (100 or $200 \mathrm{mg} / \mathrm{kg} \mathrm{b.w)} \mathrm{extracted} \mathrm{from} \mathrm{irradiated} \mathrm{plants}$ were able to diminish the CFU in blood, indicating that gamma irradiation of the plants did not have any harmful significant effects in the antibacterial activity of the E.Os $(P>0.05)$. Also, there is no significant difference $(P>0.05)$ between the non irradiated and irradiated peppermint at 100 and $200 \mathrm{mg} / \mathrm{kg}$ b.w dose ( $25 \mathrm{kGy})$. Furthermore, the different results among irradiated groups (10 and $20 \mathrm{kGy})$ of all three E.Os weren't significant $(P>0.05)$.

Oxidative injury parameters in septic rats treated with CM, ZM and MP E.O s before and after gamma irradiation:

As shown in Tables 2-4, CLP operation caused a significant increase $(P<0.05)$ in TBARS as compared to the control group. Treatments of rats with essential oils extracted from the CM, ZM and MP at the doses of 100 and $200 \mathrm{mg} / \mathrm{kg}$ b.w significantly decreased the LP levels $(P<0.05)$. Also, the MPO activity was 
significantly elevated $24 \mathrm{~h}$ post CLP in the liver as compared with control group $(P<0.05)$. Administration of the rats with the E.O $\mathrm{O}_{\mathrm{s}}$ obtained from plants $(100$ and 200 $\mathrm{mg} / \mathrm{kg} \mathrm{b.w})$ depleted the liver MPO activity to the normal value $(P<0.05)$. In addition, the GSH concentrations diminished in CLP group as compared to the control group $(P<0.05)$. However, the GSH level increased significantly $(P<0.05)$ in the treated groups with CM, ZM and MP E.Os (100 and $200 \mathrm{mg} / \mathrm{kg} \mathrm{b.w)}(P<0.05)$.

There were no differences on suppressing the hepatic TBARS level, MPO activity as well as increasing the GSH level, between E.Os extracted from the non-irradiated plants in comparison to E. $\mathrm{O}_{\text {s }}$ pulled out from irradiated ones $(\mathrm{P}>0.05)$. In other words, the E. $\mathrm{O}_{\mathrm{s}}$ derived from irradiated CM, ZM and MP as well as non-irradiated ones could modulate the oxidative injury parameters in septic rats $(P<0.05)$. Moreover, there were no differences (for all biochemical parameters) on the efficacy of the oil between 100 $\mathrm{mg} / \mathrm{kg}$ b.w and $200 \mathrm{mg} / \mathrm{kg}$ b.w $(P>0.05)$. According to the results, the differences among the irradiated groups ( 10 and $25 \mathrm{kGy})$ of all E. $\mathrm{O}_{\mathrm{s}}$ in all biochemical parameters $(\mathrm{LP}, \mathrm{GSH}$ and MPO) weren't considerable $(P>0.05)$.

Table No.2: Hepatic oxidative parameters in sepsis rats treated with Cuminum cyminum L. (CM) E.Os before and after gamma irradiation

\begin{tabular}{|c|c|c|c|}
\hline Groups & $\begin{array}{l}\text { TBARS } \quad(\mathbf{n m o l} / \mathrm{gr} \\
\text { liver })\end{array}$ & $\begin{array}{l}\text { MPO (U/mg } \\
\text { liver) }\end{array}$ & $\begin{array}{l}\text { GSH } \\
\text { liver })\end{array} \quad(\mu \mathrm{mol} / \mathrm{gr}$ \\
\hline Laparotomy (DMSO) & $16.3 \pm 0.5$ & $4.2 \pm 0.3$ & $47.8 \pm 3.3$ \\
\hline CLP (DMSO) & $28.6 \pm 1.6^{*}$ & $9.6 \pm 0.6^{*}$ & $11.8 \pm 2.5^{*}$ \\
\hline $\begin{array}{l}\text { CLP + non-irradiated CME.Os } \\
(100 \mathrm{mg} / \mathrm{kg} \text { b.w })\end{array}$ & $13 \pm 1.8 * *$ & $5.8 \pm 0.4 * *$ & $34.5 \pm 3.1^{* *}$ \\
\hline $\begin{array}{l}\text { CLP + Irradiated CM E.Os (10 } \\
\text { kGy) } \\
(100 \mathrm{mg} / \mathrm{kg} \mathrm{b.w})\end{array}$ & $15.1 \pm 2.1 * *$ & $5.8 \pm 0.1 * *$ & $34.7 \pm 1.9 * *$ \\
\hline $\begin{array}{l}\text { CLP + Irradiated CM E.Os (25 } \\
\text { kGy) } \\
(100 \mathrm{mg} / \mathrm{kg} \mathrm{b.w})\end{array}$ & $15.1 \pm 2.7 * *$ & $5.7 \pm 0.4 * *$ & $35.4 \pm 2 * *$ \\
\hline $\begin{array}{l}\text { CLP + non-irradiated CM E.Os } \\
(200 \mathrm{mg} / \mathrm{kg} \text { b.w })\end{array}$ & $13 \pm 1.2 * *$ & $6 \pm 0.3 * *$ & $35.5 \pm 1.6^{* *}$ \\
\hline $\begin{array}{l}\text { CLP + Irradiated CM E.Os (10 } \\
\text { kGy) } \\
(200 \mathrm{mg} / \mathrm{kg} \mathrm{b.w})\end{array}$ & $14.4 \pm 0.2 * *$ & $5.9 \pm 0.4 * *$ & $34.8 \pm 1.2 * *$ \\
\hline $\begin{array}{l}\text { CLP + Irradiated CM E.Os (25 } \\
\text { kGy) } \\
(200 \mathrm{mg} / \mathrm{kg} \text { b.w })\end{array}$ & $15.2 \pm 1.4 * *$ & $6 \pm 0.5 * *$ & $35 \pm 2.7 * *$ \\
\hline
\end{tabular}

In Sham- operated group (SOP), rats were undergone laparotomy and received DMSO as vehicle; In CLP group, the CLP operation was done and animals received vehicle alone; CLP+ essential oils (E.Os) groups, E.Os (100 \& $200 \mathrm{mg} / \mathrm{kg} \mathrm{b.w)} \mathrm{were} \mathrm{injected} \mathrm{(i.p)}$ immediately after CLP operation. Values of mean \pm SEM obtained from five rats. $* \mathrm{P}<0.05$ is considered significantly different from laparatomy group. $* * \mathrm{P}<0.05$ is considered significantly different from CLP group within each group. 
Anti-septic activity of irradiated plant oils

Table No.3: Hepatic oxidative parameters in sepsis rats treated with Zataria multiflora Boiss. (ZM) E.O $\mathrm{O}_{\mathrm{s}}$ before and after gamma irradiation

\begin{tabular}{|c|c|c|c|}
\hline Groups & $\begin{array}{l}\text { TBARS } \quad(\mathrm{nmol} / \mathrm{gr} \\
\text { liver })\end{array}$ & $\begin{array}{l}\text { MPO } \quad(\mathrm{U} / \mathrm{mg} \\
\text { liver })\end{array}$ & $\begin{array}{ccc}\text { GSH } & (\mu \mathrm{mol} / \quad \text { gr } \\
\text { liver })\end{array}$ \\
\hline Laparotomy (DMSO) & $16.3 \pm 0.5$ & $4.2 \pm 0.3$ & $47.8 \pm 3.3$ \\
\hline CLP (DMSO) & $28.6 \pm 1.6^{*}$ & $9.6 \pm 0.6^{*}$ & $11.8 \pm 2.5^{*}$ \\
\hline $\begin{array}{l}\text { CLP + non-irradiated ZM E.Os } \\
(100 \mathrm{mg} / \mathrm{kg} \text { b.w })\end{array}$ & $21.9 \pm 2.6^{* *}$ & $5.4 \pm 0.3 * *$ & $39.3 \pm 1.9 * *$ \\
\hline $\begin{array}{l}\text { CLP + Irradiated ZM E.Os (10 } \\
\mathrm{kGy}) \\
(100 \mathrm{mg} / \mathrm{kg} \mathrm{b.w})\end{array}$ & $16.7 \pm 3 * *$ & $4.7 \pm 0.7 * *$ & $45.8 \pm 7.6^{* *}$ \\
\hline $\begin{array}{l}\text { CLP + Irradiated ZM E.Os (25 } \\
\text { kGy) } \\
(100 \mathrm{mg} / \mathrm{kg} \mathrm{b.w})\end{array}$ & $16.9 \pm 0.5^{* *}$ & $5 \pm 0.4 * *$ & $44.9 \pm 4.6^{* *}$ \\
\hline $\begin{array}{l}\text { CLP + non-irradiated ZM E.Os } \\
(200 \mathrm{mg} / \mathrm{kg} \text { b.w })\end{array}$ & $18.8 \pm 0.5^{* *}$ & $5.4 \pm 0.6^{* *}$ & $48.5 \pm 2.8^{* *}$ \\
\hline $\begin{array}{l}\text { CLP + Irradiated ZM E.Os (10 } \\
\mathrm{kGy}) \\
(200 \mathrm{mg} / \mathrm{kg} \mathrm{b.w})\end{array}$ & $15.7 \pm 1.1 * *$ & $5.3 \pm 0.4 * *$ & $39 \pm 2.5^{* *}$ \\
\hline $\begin{array}{l}\text { CLP + Irradiated ZM E.Os (25 } \\
\text { kGy) } \\
(200 \mathrm{mg} / \mathrm{kg} \mathrm{b.w})\end{array}$ & $15.2 \pm 0.84 * *$ & $5.4 \pm 0.5^{* *}$ & $38.5 \pm 3.1 * *$ \\
\hline
\end{tabular}

In Sham- operated group (SOP), rats were undergone laparotomy and received DMSO as vehicle; In CLP group, the CLP operation was done and animals received vehicle alone; CLP+ essential oils (E.Os) groups, E.Os (100 \& $200 \mathrm{mg} / \mathrm{kg}$ b.w) were injected (i.p) immediately after CLP operation. Values of mean \pm SEM obtained from five rats. $* \mathrm{P}<0.05$ is considered significantly different from laparatomy group. $* * \mathrm{P}<0.05$ is considered significantly different from CLP group within each group.

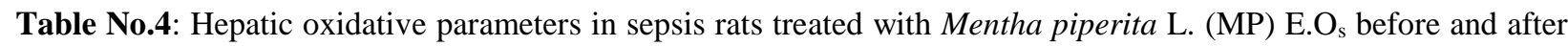
gamma irradiation

\begin{tabular}{|c|c|c|c|}
\hline Groups & $\begin{array}{l}\text { TBARS } \\
\text { liver })\end{array} \quad$ (nmol/gr & $\begin{array}{l}\text { MPO } \quad(\mathbf{U} / \mathbf{m g} \\
\text { liver })\end{array}$ & $\begin{array}{l}\text { GSH } \quad(\mu \mathrm{mol} / \mathrm{gr} \\
\text { liver })\end{array}$ \\
\hline Laparotomy (DMSO) & $16.3 \pm 0.5$ & $4.2 \pm 0.3$ & $47.8 \pm 3.3$ \\
\hline CLP (DMSO) & $28.6 \pm 1.6^{*}$ & $9.6 \pm 0.6^{*}$ & $11.8 \pm 2.5^{*}$ \\
\hline $\begin{array}{l}\text { CLP + non-irradiated MP E.Os } \\
(100 \mathrm{mg} / \mathrm{kg} \text { b.w })\end{array}$ & $11.1 \pm 1.6^{* *}$ & $6.3 \pm 0.2 * *$ & $35.8 \pm 7.2 * *$ \\
\hline $\begin{array}{l}\text { CLP + Irradiated MP E.Os (10 } \\
\text { kGy) } \\
(100 \mathrm{mg} / \mathrm{kg} \mathrm{b.w})\end{array}$ & $20.5 \pm 3.2 * *$ & $5.7 \pm 0.4 * *$ & $43.1 \pm 3.9 * *$ \\
\hline $\begin{array}{l}\text { CLP + Irradiated MP E.Os (25 } \\
\text { kGy) } \\
(100 \mathrm{mg} / \mathrm{kg} \text { b.w })\end{array}$ & $16 \pm 3.6^{* *}$ & $5.7 \pm 0.4 * *$ & $32.5 \pm 3.3 * *$ \\
\hline $\begin{array}{l}\text { CLP + non-irradiated MP E.Os } \\
(200 \mathrm{mg} / \mathrm{kg} \mathrm{b.w})\end{array}$ & $18.4 \pm 2.1 * *$ & $5.8 \pm 0.2 * *$ & $34.7 \pm 1.7 * *$ \\
\hline $\begin{array}{l}\text { CLP + Irradiated MP E.Os (10 } \\
\text { kGy) } \\
(200 \mathrm{mg} / \mathrm{kg} \mathrm{b.w})\end{array}$ & $15.2 \pm 1.1 * *$ & $5.7 \pm 0.3 * *$ & $39.5 \pm 7.3 * *$ \\
\hline $\begin{array}{l}\text { CLP + Irradiated MP E.Os (25 } \\
\text { kGy) } \\
(200 \mathrm{mg} / \mathrm{kg} \mathrm{b.w})\end{array}$ & $14 \pm 0.4 * *$ & $5.9 \pm 0.2 * *$ & $35 \pm 5 * *$ \\
\hline
\end{tabular}

In Sham- operated group (SOP), rats were undergone laparotomy and received DMSO as vehicle; In CLP group, the CLP operation was done and animals received vehicle alone; CLP+ essential oils (E.Os) groups, E.Os (100 \& $200 \mathrm{mg} / \mathrm{kg}$ b.w) were injected (i.p) immediately after CLP operation. Values of mean \pm SEM obtained from five rats. $* \mathrm{P}<0.05$ is considered significantly different from laparatomy group. $* * \mathrm{P}<0.05$ is considered significantly different from CLP group within each group. 


\section{DISCUSSION}

Based on our previous data, the in vivo antibacterial activities of three oils extracted from $\mathrm{CM}, \mathrm{ZM}$ and MP were informed by reducing the number of CFUs from the bloodstream increased significantly after CLP surgery. Also, the in vitro strong antibacterial activities of three oils against gram-positive and gram-negative bacteria by the determination the minimal inhibitory (MIC) and minimal bacterial concentrations (MBC) overlapped with the in vivo results ${ }^{35-37}$. The evidences presented in our recent articles showed that the antioxidant capacities of the three oils remarkable in vitro system could be attributed to their main phytochemical components $\mathrm{s}^{7-10}$. In followings, in the present study, the role of gamma irradiation as a modern decontamination method in the protective effects of three oils on oxidative injury parameters in septic rats induced by CLP rat model were investigated. Our aim is to access whether the in vitro and in vivo antibacterial and antioxidant activities of three oils can protect the liver from damages even after irradiation exposure thorough the CLP method which was the most practical method of sepsis.

Our data indicated that the essential oils extracted from CM, ZM and MP could adjust antioxidant defense system by changing the oxidative stress parameters namely; LP, MPO and GSH disturbed in septic rats (Tables 1-4). It seems that the oil therapeutic effects can be mainly due to its intervention with the mediators of oxidative stress/antioxidant parameters disturbed by sepsis.

In sepsis, myeloperoxidase (MPO) - a hemeprotein secreted by activated leukocytes - amplifies the oxidizing potential of $\mathrm{H} 2 \mathrm{O} 2$ by using it as co-substrate to generate reactive intermediates that promote $\mathrm{LP}^{42}$. Increased concentrations of LP and MPO are found in rats with sepsis ${ }^{43-46}$, and tissue MPO is a marker of LP levels that increase when septic shock is induced by CLP in rats ${ }^{47}$. Our study confirmed the elevation of LP level and MPO activity in septic rats (Tables 1-4). In addition, this study indicated the oil hepatic protective activity in rats treated with three E. $\mathrm{O}_{\mathrm{s}}$ through significant decrease in the liver MPO activity caused to the suppressed hepatic LP $(P<0.05)$ (Tables 2-4). In addition, GSH is an important constituent of intracellular protective mechanisms against oxidative stress ${ }^{48}$. So, the GSH recuperation in rats treated with all the E. $\mathrm{O}_{\mathrm{s}}$ showed their hepatoprotective effects. These data are in agreement with the report of Villa ${ }^{6}$ who reported the protective role of GSH against sepsis. Other studies have also indicated that antioxidants such as silymarin and Nacetylcysteine (NAC), which maintain the cellular defense mechanisms, could protect oxidative tissue damage caused by sepsis ${ }^{49}$. Besides, The reduction of hepatic LP concomitant with the replenishment of GSH content by all E.Os (Tables 2-4) represented that the oils have great potential in maintaining the oxidative/antioxidant balance. Other studies confirmed these results, reported that Nigella sativa ethanolic extract prevented lung injury induced by CLP through modulating the LP, GSH levels and MPO activity ${ }^{50}$. Sildenafil is a highly protective agent in preventing lung and kidney damages caused by CLP-induced sepsis via maintenance of the oxidative/antioxidant status such as LP, GSH and MPO activity ${ }^{51}$. Also, curcumin protects against sepsis-induced acute lung injury in rats with counteract the inflammatory cells infiltration and, hence, ROS generation and regulate cytokine effects $^{52}$.

On the other hand, our data indicated that the irradiated groups (10 and $25 \mathrm{kGy}$ ) as same as non -irradiated ones have significant effects on the potential of hepatoprotective activities of the three E.Os $(100$ and $200 \mathrm{mg} / \mathrm{kg} \mathrm{b.w})$. It means that the oils at both doses (100 and $200 \mathrm{mg} / \mathrm{kg}$ b.w) extracted from irradiated $\mathrm{ZM}$ aerial parts, MP leaves and CM at 10 and $25 \mathrm{kGy}$, as well as non -irradiated ones, could modulate the hepatic antioxidant/oxidative stress statue by decreasing the MPO and 
Anti-septic activity of irradiated plant oils

LP levels concomitant with increasing GSH level (Tables 2-4). These results correlate with our recent findings that gamma irradiation to caraway seeds did not have any significant effects on the oil hepatoprotective activity in septic rats ${ }^{37}$. One study reported the application of $\gamma$-radiation at doses from 5 to $30 \mathrm{kGy}$ did not cause any significant changes in the total phenolic content and antioxidant activities of caraway and bay leaves extracts ${ }^{53}$.

It is well known that hepatoprotective effects are associated with plants including efficient antioxidant compounds ${ }^{54,55}$. Our GC/GC mass analysis showed that the main chemical compositions of the essential oils isolated from CM were $\beta$-pinene $(24.07 \%)$, $\gamma$-terpinene-7-al (21.48\%), $\gamma$-terpinene $(20.09 \%)$, cumin aldehyde $(19.03 \%)$ and $p$ cymene $(10.2 \%)^{33}$. Also, the major compounds of ZM essential oils were thymol $(61.8 \%)$, carvacrol $(10.5 \%), p$-cymene $(7.5 \%)$, and $\gamma$-terpinene $(4.4 \%)^{32}$. We also considered Persian MP with the main chemical components as menthol (50.9\%), menthone (14.9\%), $\alpha$-gurjunene (8.7\%), neo-menthol (6.5\%) and 1, 8-cineole $(3.7 \%)^{34}$. In other words, the antioxidant activities of these herbs could be attributed to their main active antioxidant components such as phenols and flavonoids; for example the existence of phenolic monoterpenes including carvacrol and thymol in $\mathrm{ZM}$ oils and menthone and menthol in MP oils and $\beta$-pinene and $\gamma$-terpinene in the $\mathrm{CM}$ oils $^{32-34}$. Previous studies also confirmed the main role of antioxidants in chemopreventive effects of the natural products ${ }^{56-57}$. Antioxidants can reduce the damages of oxidative stresses by scavenging free radicals ${ }^{58}$. Other data was demonstrated that the essential oil of rosemary containing antioxidative compounds, namely 1, 8-cineole, camphor and $\alpha$-pinene, possess a strong antioxidant and hepatoprotective activities ${ }^{59}$. Also, Nithianantham ${ }^{40}$ reported the hepatoprotective activity of Clitoria ternatea leaf may be due to its free radical scavenging and antioxidant activity, resulting from the presence of some antioxidant compounds in the extracts ${ }^{60}$. In addition, the lack of change in the composition, antioxidant and radical scavenging properties of the oils after plant gamma irradiation ${ }^{32-34}$, confirmed the association between antioxidant compounds and oil hepatoprotective activity.

In the other hand, the in vitro and in vivo antibacterial activities explained in our recent studies ${ }^{35-37}$ indicated that i.p administrations of the E. $\mathrm{O}_{\text {s }}$ may have direct contact with the bacteria in the peritoneum which can validate the microbicidal effect leading to an increased bacterial clearance in $24 \mathrm{~h}$ post CLP ${ }^{61}$. The CLP model seems to resemble qualitatively as well as quantitatively the clinical observations of vascular reactivity and inflammation during polymicrobial peritonitis, bacteremia and systemic sepsis ${ }^{62}$. The cecum contains a huge concentration of microbes, which are a combination of gram-negative and gram-positive flora. The ligation of the cecum produces a source of ischemic tissue and polymicrobial infection indeed. This combination of ischemic/necrotic tissue and microbial infection distinguishes this multifactorial model from a number of other bacterial sepsis models. After replacing the punctured cecum into peritoneum, a severe peritonitis happened due to start decanting the fecal contents into the abdomen ${ }^{63}$. Our results (Table 1) indicated that the bacteria will be detectable on the blood and peritoneum within 24 hours in CLP groups. While, the administration of the both non -irradiated and irradiated treatment groups including the three E. $\mathrm{O}_{\mathrm{s}}(100$ and $20 \mathrm{mg} / \mathrm{kg} \mathrm{b.w)}$ derived from the different medicinal plants could surprisingly decrease the CFU counts when compared with the CLP ones $(P<0.05)$. One study reported that the administration of Myrrh (an Indian plant) led to a remarkable increase in survival and an increased bacterial clearance in mice with lethal sepsis induced by CLP ${ }^{63}$. 


\section{CONCLUSION}

This study indicated the effectiveness of the E. $\mathrm{O}_{\mathrm{s}}$ extracted from CM, ZM and MP at both doses (100 and $200 \mathrm{mg} / \mathrm{kg} \mathrm{b.w}$ ) by reducing the LP level and MPO activity as well as raising the GSH concentration in septic rats after CLP operation. In addition, gamma irradiations (10 and $25 \mathrm{kGy}$ ) were suggested as a safe method for decontamination of the three medicinal plants in order not to considerably change in the efficiency of the E. $\mathrm{O}_{\mathrm{s}}$ indicating the potent modulatory anti-septic activity.

\section{REFERENCES}

1. Zolali E, Hamishehkar H, Maleki-Dizaji N, Majidi Zolbanin N, Ghavimi H, Kouhsoltani M, Asgharian P. Selenium effect on oxidative stress factors in septic rats. Adv Pharm Bull. 2014; 4:289-293.

2. Peralta JG, Lesly S, Evelson P. Oxidative stress in skeletal muscle during sepsis in rats. Circ Shock. 1993; 39: 153-159.

3. Hubbard WJ, Choudhry M, Schwacha MG, Kerby JD. Cecal ligation and puncture. Shock. 2005; 24: 52-57.

4. Gutteridge JMC. Lipid peroxidation and antioxidants as biomarkers of tissue damage. Clin Chem. 1995; 41: 1819-1828.

5. Sener G, Toklu H, Ercan F, Erkanli G. Protective effect of beta-glucan against oxidative organ injury in a rat model of sepsis. Int Immunopharmacology. 2005; 5 : 1387-1396.

6. Villa P, Saccani A, Sica A. Glutathione protects mice from lethal sepsis by limiting inflammation and potentiating host defense. J Infect Dis. 2002; 185: 1115-1120.7. Hosseinzadeh H, Ramezani M, Salmani GA. Antinociceptive, anti-inflammatory and acute toxicity effects of Zataria Multiflora Boiss extracts in mice and rats. J Ethnopharmacol. 2000; 73: 379-385.

7. Iranian Herbal Pharmacopoeia. Ministry of Health and Medical Publications, Tehran. 2002; pp. 51-56.

8. Sharififar F, Moshafi MH, Mansouri SH, Khodashenas M, Khoshnoodi M. In vitro evaluation of antibacterial and antioxidant activities of the essential oil and methanol extract of endemic Zataria Multiflora Boiss. Food Control. 2007; 18: 800-805.

9. Moshafi MH, Mansouri SH, Sharififar F, Khoshnoodi M. Antibacterial and antioxidant effects of the essential oil and extract of Zataria Multiflora Boiss. J Kerman Uni Med Sci. 2007; 14: 33-43.

10. Shokrzadeh M, Chabra A, Ahmadi A, Naghshvar F, Habibi E, Salehi F, Assadpour S. Hepatoprotective Effects of Zataria Multiflora Ethanolic Extract on Liver Toxicity Induced by Cyclophosphamide in Mice. Drug Res (Stuttg). In press; 2014.

11. Kavoosi G, Teixeira da, Silva JA, Saharkhiz MJ. Inhibitory effects of Zataria Multiflora essential oil and its main components on nitric oxide and hydrogen peroxide production in lipopolysaccharide-stimulated macrophages. J Pharm Pharmacol. 2012; 64: 1491-500.

12. Deepak. Importance of , Indian journal of traditional Morton, J. F. Herbs and Spices. 2013; Golden Press: New York. 1976; p 160

13. Morton JF. Herbs and Spices; Golden Press: New York. 1976; p 160.13.Dorman HJD \& Deans SG. Antimicrobial agents from plants: Antibacterial activity of plant volatile oils. J Appl Microbiol. 2000; 88: 308-316.

14. Dorman HJD \& Deans SG. Antimicrobial agents from plants: Antibacterial activity of plant volatile oils. J Appl Microbiol. 2000; 88: 308-316.

15. Rodov V, Vinokur Y, Gogia N, Chkhikvishvili L. Hydrophilic and lipophilic antioxidant capacities of Georgian spices for meat and their possible health implications. Georgian Med News. 2010; 179: 61-66.

16. Zargary A. Medicinal plants, Tehran university publishications: Tehran, Iran., 2001. 
Anti-septic activity of irradiated plant oils

17. Samani KG, Farrokhi E. Effects of cumin extract on oxLDL, paraoxanase 1 activity, FBS, total cholesterol, triglycerides, HDL-C, LDL-C, Apo A1, and Apo B in in the patients with hypercholesterolemia. Int J Health Sci (Qassim). 2014; 8: 39-43.

18. Sariçoban C, Yilmaz MT. Effect of thyme/cumin essential oils and butylated hydroxyl anisole/butylated hydroxyl toluene on physicochemical properties and oxidative/microbial stability of chicken patties. Poult Sci 2014; 93: 456-63.

19. Foster S. Peppermint, Mentha piperita. In Botanical Series; American Botanical Council: Austin, TX, 1990; no 306.

20. Brown D. Encyclopaedia of Herbs and Their Uses. Dorling Kindersley: London, U. K., 1995.

21. Bisset N G. Herbal Drugs. Medpharm Scientific Publishers: Stuttgart, Germany, 1994.

22. Tyler V E. The Honest Herbal. Pharmaceutical Products Press: New York, 1993.

23. Baytop T. Türkiyede Bitkiler ile TedaVi-Gecümisüten Bugüne (Therapy with Medicinal Plants in Turkey-Past and Present), $2^{\text {nd }}$ ed.; Nobel Tip Basımevi: Istanbul, Turkey. 1999; pp; 348-349.

24. Hendriks H. Pharmaceutical Aspects of Some Mentha Herbs and Their Essential Oils. Perfum. FlaVor. 1998; 23: 15-23.

25. Cowan MM. Plant Products As Antimicrobial Agents. Clin. Microbiol. ReV. 1999; 12: $564-582$.

26. Kasem RF, Hegazy RH, Arafa MA, AbdelMohsen MM. Chemopreventive effect of Mentha piperita on dimethylbenz[a]anthracene and formaldehyde-induced tongue carcinogenesis in mice (histological and immunohistochemical study). J Oral Pathol Med. 2014; 43: 484-91.

27. Hassan HA, Hafez HS, Goda MS. Mentha piperita as a pivotal neuro-protective agent against gamma irradiation induced DNA fragmentation and apoptosis: Mentha extract as a neuroprotective against gamma irradiation. Cytotechnology. 2013; 65: 145-56.

28. Mahindru SN. Food preservation and irradiation, 1st ed. Saujanya Books, New Delhi; 2005.

29. FAO/WHO Revised Codex General Standard for Irradiated Foods. Codex Stan. 106-1983, Rev (2003).

30. Code of Federal Regulation 21CFR179 (Revised as of April 1): Irradiation in the Production, Processing and Handling of Food, Title 21, V3 (2004).

31. Fatemi F, Asri Y, Rasooli I, Alipoor ShD, Shaterloo M. Chemical composition and antioxidant properties of $\gamma$-irradiated Iranian Zataria Multiflora extracts. Pharm Biol. 2012; 50: 232-8.

32. Fatemi F, Dadkhah A, Rezaei MB, Dini S. Effect of $\gamma$-irradiation on the chemical composition and antioxidant properties of cumin extracts. J Food Biochem. 2013; 37: 432-439.

33. Fatemi F, Dini S, Rezaei MB, Dadkhah A, Dabbagh R, Naij S. The effect of $\gamma$ irradiation on the chemical composition and antioxidant activities of peppermint essential oil and extract. J Essent Oil Res. 2014a; 26; 97-104.

34. Fatemi F, Dini S, Dadkhah A, Zolfaghari MR. Considering the antibacterial activity of Zataria multiflora Boiss essential oil treated with gamma-irradiation In vitro and In vivo systems. Radiat Phys Chem. 2014b; In Press.

35. Jalali Yazdi A, Zolfaghari MR, Dadkhah A, Fatemi F. Effect of $\gamma$-irradiation on the Antibacterial Activities of Cuminum cyminum L. Essential Oils in vitro and in vivo systems. JEOP. 2014; In Press.

36. Ghanooni Sh, Dadkhah A, Zolfaghari MR, Fatemi F. Evaluation of $\gamma$-irradiation treatment on the antibacterial activities of Mentha piperita L. essential oils In vitro and In vivo systems (CLP inflammatory model) . Iran J Radiat Res. 2014; In Press.

37. Fatemi F, Allameh A, Khalaf H, Ashrafihelan J. Hepatoprotective effects of gammairradiated caraway essential oils in experimental sepsis. Appl Radiat Isot. 2010; 68: 280-5. 
38. Hillegass LM, Griswold DE, Brickson B, Albrightson-Winslow C. Assessment of myeloperoxidase activity in whole rat kidney. J Pharmacol Method. 1990; 24: 285 295.

39. Buege JA, Aust SD. Microsomal lipid peroxidation. In: Packer, L (Ed.) Meth. Enzymol. 1978; 52: 302-310.

40. Sedlak J, Lindsay RH. Estimation of total protein with bound and non-protein sulfhydryl groups in tissues with Ellman's reagent. Anal Biochem. 1968; 25: 192205.

41. Podrez EA, Abu-Soud HM, Hazen SL. Myeloperoxidase-generated oxidants and atherosclerosis. Free Radical Bio Med. 2000; 28: 1717-1725.

42. Cuzzocrea $S$, et al. Protective effects of n-acetylcysteine on lung injury and red blood cell modification induced by carrageenan in the rat. FASEB J. 2001; 15: 1187-200.

43. Ogilvie AC, Groeneveld AB, Straub JP, Thijs LG. Plasma lipid peroxides and antioxidants in human septic shock. Intens Care Med. 1991; 17: 40-4.

44. Soriano FG, et al. Resistance to acute septic peritonitis in poly(ADP-ribose) polymerase-1-deficient mice. Shock. 2002; 17: 286-92.

45. Kharb S, Singh V, Ghalaut PS, Sharma A, Singh GP. Role of oxygen free radicals in shock. J Assoc Physicians India. 2000; 48: 956-7.

46. Kannan R, Kuhlenkamp JF, Jeandidier E, Trinh H, Ookhtens M, Kaplowitz N. Evidence for carrier-mediated transport of glutathione across the blood-brain barrier in the rat. J Clin Invest. 1990; 85: 2009-13.

47. Toklu HZ, Tunali Akbay T, Velioglu-Ogunc A, Ercan F, Gedik N, Keyer-Uysal M, Sener G. Silymarin, the antioxidant component of Silybum marianum, prevents sepsis-induced acute lung and brain injury. J Surg Res. 2008; 145: 214-222.

48. Bayir Y, et al. Nigella sativa as a potential therapy for the treatment of lung injury caused by cecal ligation and puncture-induced sepsis model in rats. Cell Mol Biol (Noisy-le-grand). 2012; 15, 58 Suppl: OL1680-7.50. Cadirci E, Halici Z, Odabasoglu F, Albayrak A, Karakus E, Unal D, Atalay F, Ferah I, Unal B. Sildenafil treatment attenuates lung and kidney injury due to overproduction of oxidant activity in a rat model of sepsis: a biochemical and histopathological study. Clin Exp Immunol. 2011; 166: 374-84.

49. Xiao X, Yang M, Sun D, Sun S. Curcumin protects against sepsis-induced acute lung injury in rats. J Surg Res. 2012; 176: e31-9.

50. Huang B, Ban X, He J, Tong J, Tian J, Wang Y. Hepatoprotective and antioxidant activity of ethanolic extracts of edible lotus (Nelumbo nucifera Gaertn.) leaves. Food Chem. 2010; 120: 873-878.

51. Nayak SS, Jain R, Sahoo AK. Hepatoprotective activity of Glycosmis pentaphylla against paracetamol-induced hepatotoxicity in Swiss albino mice. Pharm Biol. 2011; 49: 111-7.

52. Khan R, Sultana S. Farnesol attenuates 1,2-dimethylhydrazine induced oxidative stress, inflammation and apoptotic responses in the colon of Wistar rats. ChemicoBiological Interactions. 2011; 192 (3): 193-200.

53. Kaliora AC, Kountouri AM. Chemopreventive Activity of Mediterranean edicinal Plants, Cancer Prevention - From Mechanisms to Translational Benefits, Dr. Alexandros G. Georgakilas (Ed.), ISBN: 978-953- 51-0547-3, InTech, Available from: (2012),

54. Kharpate S, Vadnerkar G, Jain D and Jain S. Hepatoprotective activity of the ethanol extract of the leaf of Ptrospermum acerifolium. Indian J Pharm. Sci. 2007; 69(6):850-852.

55. Rašković A, Milanović I, Pavlović N, Cebović T, Vukmirović S, Mikov M. Antioxidant activity of rosemary (Rosmarinus officinalis L.) essential oil and its hepatoprotective potential. BMC Complement Altern Med. 2014; 14: 225.

56. Nithianantham K, Shyamala M, Chen Y, Latha LY, Jothy SL, Sasidharan S. Hepatoprotective potential of Clitoria ternatea leaf extract against paracetamol induced damage in mice. Molecules. 2011; 6: 10134-45.

57. Maciel MCG, Farias JC, Maluf MJ, Gomes EA, Pereira PVS, Aragao-Filho WC, Frazao JB, Costa GC, Sousa SM, Silva LA, Amaral FMM, Russo M, Guerra RNM, 
Anti-septic activity of irradiated plant oils

Nascimento FRF. Syzygium jambolanum treatment improves survival in lethal sepsis induced in mice. BMC Complement Altern Med. 2008; 8: 57.

58. Riedemann NC, Guo RF, Ward PA. The enigma of sepsis. J Clin Invest. 2003; 112: 460-467.

59. Cuenca AG, Delano MJ, Kelly-Scumpia KM, Moldawer LL, Efron PA. Current protocols in immunology: cecal ligation and puncture. Curr Protoc Immunol. 2010. doi: 10.1002/ 0471142735.im1913s91.

60. Thatte UM, Kulkarni MR, Dahanukar SA. Immunotherapeutic modification of Escherichia coli peritonitis and bacteremia by Tinospora cordifolia. J Postgrad Med. 1992; 38: 5-13.

Received: February 03, 2016; Accepted: July 14, 2016 